\title{
PEPTIC ULCER FREQUENCY DIFFERENCES RELATED TO H. PYLORI OR AINES
}

\author{
Diego Michelon de CARLI', 2, Rafael Cardoso PIRES'1, Sofia Laura ROHDE'1, \\ Caroline Mayara KAVALCO ${ }^{1}$ and Renato Borges FAGUNDES ${ }^{1,3}$
}

\begin{abstract}
Background - Peptic ulcer etiology has been changing because of H. pylori decline. Objective - To estimate peptic ulcer prevalence in 10 years-interval and compare the association with $H$. pylori and use of non-steroidal anti-inflammatory drugs. Methods Records assessment in two periods: A (1997-2000) and B (2007-2010), searching for peptic ulcer, H. pylori infection and non-steroidal anti-inflammatory drugs use. Results - Peptic ulcer occurred in $30.35 \%$ in A and in $20.19 \%$ in B. H. pylori infection occurred in $73.3 \%$ cases in A and in $46.4 \%$ in B. Non-steroidal anti-inflammatory drugs use was $3.5 \%$ in A and $13.3 \%$ in B. Neither condition occurred in $10.4 \%$ and $20.5 \%$ in A and B respectively. Comparing both periods, we observed reduction of peptic ulcer associated to H. pylori $(P=0.000)$, increase of peptic ulcer related to non-steroidal anti-inflammatory drugs $(P=0.000)$ and idiopathic peptic ulcer $(P=0.002)$. The concurrent association of $H$. pylori and non-steroidal anti-inflammatory drugs was also higher in $\mathrm{B}(P=0.002)$. Rates of gastric ulcer were higher and duodenal ulcer lower in the second period. Conclusions - After 10 years, the prevalence of peptic ulcer decreased, as well as ulcers related to H. pylori whereas ulcers associated to non-steroidal anti-inflammatory drugs increased. There was an inversion in the pattern of gastric and duodenal ulcer and a rise of idiopathic peptic ulcer.
\end{abstract}

HEADINGS - Peptic ulcer. Helicobacter pylori. Non-steroidal anti-inflammatory agents. Stomach ulcer. Duodenal ulcer.

\section{INTRODUCTION}

Until the discovery of the association of peptic ulcer disease (PUD) with Helicobacter pylori $(H$. pylori) infection in 1983 by Marshall and Warren ${ }^{(13)}$, PUD etiology was uncertain. Since there, the literature has shown that $H$. pylori infection and non-steroidal anti-inflammatory drugs (NSAID) were the most common causes of peptic ulcer ${ }^{(3,10)}$.

Studies from the 1980s and 1990s, showed the prevalence of $H$. pylori infection was $90 \%$ in duodenal ulcer and $70 \%$ in the gastric ulcer ${ }^{(10)}$. The prevalence of $H$. pylori infection has been decreasing steadily over the last decades, especially in industrialized countries while the prevalence of peptic ulcer associated with the use of NSAID apparently is increasing ${ }^{(9,14,15)}$. The prevalence of peptic ulcer not related to $H$. pylori nor NSAID - idiopathic PUD - is increasing according to some studies ${ }^{(4,9,24)}$. In North America, it has been reported as $20 \%$ to $40 \%$, in Southern Europe as $4.1 \%$ to $8 \%$ and the Northern Europe as $10 \%$ to $15 \%$. Asia and undeveloped countries have low prevalence of idiopathic peptic ulcer ${ }^{(15)}$. Recent data available from Brazil still point out for high prevalence of $H$. pylori infection $^{(19,20,25)}$ and there are mismatched reports on duodenal ulcer prevalence ${ }^{(12,21)}$. Therefore, our aim was to assess and compare the prevalence of peptic ulcer disease and its association with $H$. pylori infection and use of NSAID in a population from the central region of southern Brazil, in two periods with an interval of 10 years.

\section{METHODS}

We designed a cross-sectional study to assess the endoscopy records of our Hospital in two periods: period A (1997-2000) and period B (2007-2010). We searched for the diagnosis of uncomplicated gastric and duodenal ulcer. We planned to exclude ulcers with histological diagnosis of malignancy or specific causes as Crohn's disease, Zollinger-Ellison syndrome, cytomegalovirus and other Helicobacter infection (e.g. H. heilmannii). We also excluded patients under 18 years old, cirrhotic patients with portal hypertension and patients critically ill. $H$. pylori infection was identified by histological examination. Biopsies were taken from each of the five sites listed in the Sydney system criteria ${ }^{(6)}$. We searched the patients' records for the use of NSAID before upper GI examination. We defined idiopathic ulcer disease when $H$. pylori was absent in the biopsies and there was no prior use of NSAID. We also recorded the patients' demographics (age and gender), tobacco and alcohol consumption and ulcers location. Incomplete records were excluded.

Departamento de Clínica Médica, Universidade Federal de Santa Maria - UFSM; ${ }^{2}$ Unidade de Gastroenterologia, Hospital Universitário, UFSM; ${ }^{3}$ Programa de Pós-Graduação Ciências em Gastroenterologia e Hepatologia, Universidade Federal do Rio Grande do Sul - UFRGS. Brasil.

Correspondence: Prof. Renato B. Fagundes. Avenida Grécia 1000, ap. 1002, Torre B. CEP: 91350-070 - Porto Alegre, RS, Brasil. E-mail: fagundesrb@gmail.com 
The statistical analysis compared the frequency of peptic ulcer disease and its association with $H$. pylori infection or NSAID intake in both periods. We also compared the clinical and demographic characteristics of patients. We assessed the means significance by $t$ test. With qui-square test followed by adjusted residual analyses, we evaluated the significance of ulcer's location and their association with etiology. The significance level was 0.05 . We used SPSS PASW Statistic software for Windows v.18. The Institutional Ethical Committee on Research approved the study with the number 01415912.3.00005346.

\section{RESULTS}

We searched examine the records of 2056 patients; 1232 in the period A and 824 in the period B. We identify 393 patients with uncomplicated gastric and duodenal ulcer in period A and 184 patients in period B. We excluded 37 patients because 19 presented malignant ulcers, two patients were infected by $H$. heilmannii and 16 had incomplete records. The final sample was 374 PUD patients in period A and 166 in period B. Age, gender, tobacco, alcohol consumption and ulcers location are described in Table 1 . The mean age was higher in the period $\mathrm{B}$. There was no difference related to gender, alcohol and tobacco consumption.

Peptic ulcer prevalence was $30.35 \%$ (374/1232 patients) in period A and $20.19 \%$ (166/824 patients) in period B. There was a significant statistical decrease in the prevalence of peptic ulcer after 10 years $(P=0.000)$. Prevalence of gastric ulcer was higher in period $\mathrm{B}, 73.30 \%$ vs $51.07 \%(P=0.000)$ while prevalence of duodenal ulcer was lower, $20.48 \%$ vs $40.03 \%$ $(P=0.000)$. There was no difference in the combination of both locations in the two periods $(P=0.072)$.

$H$. pylori infection and the use of NSAID are detailed on Table 2. The NSAID most commonly used in the period
A were aspirin and diclofenac and in the period $\mathrm{B}$ were aspirin and ibuprofen. NSAID indication ranged from pain syndromes to prevention of cardiovascular events and many times as self-medication. Comparing both periods (Figure 1), we observed significant reduction of peptic ulcer associated to $H$. pylori infection $(P=0.000)$, a significant increase of ulcer related to NSAID and idiopathic ulcer $(P=0.002)$. The concurrent association of $H$. pylori and NSAID was also higher in the period $\mathrm{B}(P=0.002)$.

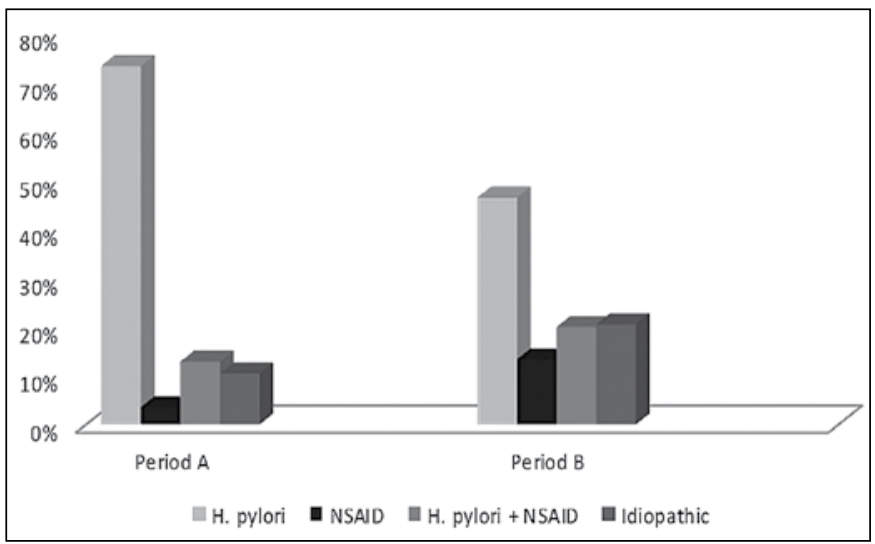

FIGURE 1. Frequency of PUD related to H. pylori and/or NSAID in the two periods

PUD: peptic ulcer disease; NSAID: non-steroidal anti-inflammatory drugs

\section{DISCUSSION}

Our results showed that the prevalence rate of PUD decreased after 10 years. We also identified the decrease of PUD related to $H$. pylori infection. While $H$. pylori infection became less prevalent, the opposite has occurred with PUD

TABLE 1. Clinical characteristics of patients

\begin{tabular}{lccc}
\hline & $\begin{array}{c}\text { Period A (1997-2000) } \\
\mathbf{n = 3 7 4}\end{array}$ & $\begin{array}{c}\text { Period B (2007-2010) } \\
\mathbf{n = 1 6 6}\end{array}$ & $\boldsymbol{P}$ value* \\
\hline Age (Mean \pm DP) & $52.43( \pm 15.18)$ & $58.75( \pm 13.87)$ & 0.000 \\
Men & $238(63.60 \%)$ & $102(61.40 \%)$ & 0.63 \\
Tobacco & $195(52.10 \%)$ & $79(47.60 \%)$ & 0.40 \\
Alcohol & $79(21.10 \%)$ & $55(22.30 \%)$ & 0.82 \\
Gastric ulcer & $191(51.07 \%)$ & $125(73.30 \%)$ & $0.000 *$ \\
Duodenal ulcer & $151(40.03 \%)$ & $34(20.48 \%)$ & $0.000 *$ \\
Gastric ulcer + Duodenal ulcer & $32(8.56 \%)$ & $7(4.22 \%)$ & $0.072 *$ \\
\hline
\end{tabular}

* Adjusted residual analysis

TABLE 2. Peptic ulcer etiology

\begin{tabular}{lccc}
\hline & Period A (1997-2000) $\mathrm{n}=374$ & Period B (2007-2010) $\mathbf{n}=166$ & $P$ value* \\
\hline & $274(73.30 \%)$ & $77(46.40 \%)$ & 0.000 \\
NSAID & $13(3.50 \%)$ & $22(13.30 \%)$ & 0.000 \\
H. pylori + NSAID & $48(12.80 \%)$ & $33(19.90 \%)$ & 0.034 \\
Idiopathic ulcer & $39(10.40 \%)$ & $34(20.50 \%)$ & 0.002 \\
\hline
\end{tabular}

* Adjusted residual analysis; NSAID: non-steroidal anti-inflammatory drugs 
related to NSAID intake, which increased in this time, as well as idiopathic PUD. The prevalence of gastric ulcer was higher and duodenal ulcer lower 10 years later.

The fall of prevalence rate of PUD and $H$. pylori infection probably is related to the improvement in social and sanitary conditions over the years ${ }^{(14)}$. We also have to consider that the widespread eradication of $H$. pylori may have a marked effect on the decrease of peptic ulcer associated with $H$. pylori infection ${ }^{(8)}$. Giving support to our findings there are many studies that identified similar results ${ }^{(2,7,14,15,16,18)}$. On the other hand, it is not a worldwide phenomenon, because in some others studies $H$. pylori still remains highly associated to $\mathrm{PUD}^{(3,22,24)}$. Those controversies could be reflecting different ethnics, genetics and environment. Brazil has many inequalities among its regions. $H$. pylori prevalence rates, among adults, have been reported as high as $87 \%$ in Northeast region ${ }^{(19)}$ and in South and Southeast regions (that have higher standard of living) those rates, still high, are lower, ranging between 62.9 to $66.5 \%{ }^{(22,25)}$. A recent study conducted in São Paulo, Brazil, reported high prevalence of duodenal ulcer related to $H$. pylori infection ${ }^{(12)}$. This study did not assess the use of NSAID and could be also reflecting different type of Brazilian population ${ }^{(11)}$ because in Rio Grande do Sul, the most southern Brazilian state, was observed a decrease of duodenal ulcer prevalence along 10 years. This study did not approach $H$. pylori status or NSAID intake ${ }^{(21)}$.

Brazil has been presenting a new demographic pattern characterized by reduction in the population growth rate and by profound transformation in its age structure, with significant increase of the elderly contingent. Those modifications have caused important changes in the population epidemiological profile ${ }^{(23)}$. NSAID is increasing its potential as a risk factor for peptic ulcer disease because the widespread consumption. NSAID are used under prescription as well as self-medication. Acetylsalicylic acid is widely prescribed for primary and secondary prevention of cardiovascular events and many others clinical conditions. NSAID are easily accessed without medical supervision and largely used for treatment of pain syndromes, such as musculoskeletal diseases ${ }^{(7,10,15)}$. Patients in the period $\mathrm{B}$ were older than patients in the period $\mathrm{A}$ and were more likely to use NSAID. This could be the explanation for the higher prevalence of NSAID ulcer in period B but it also could due a cohort effect among generations in period $\mathrm{B}$. Moreover, patients in this period could be treated for $H$. pylori eradication in this 10 -year period. Furthermore, $H$. pylori infection and NSAID are synergistic risk factors for peptic ulcer. Supporting this evidence there are other studies reporting higher prevalence of peptic ulcer associated to both risk factors in the more recent years ${ }^{(7,18)}$.

The changing pattern between duodenal and gastric location identified in our study in this 10 -years interval is in agreement with the reduction of $H$. pylori infection and the increase of NSAID use.

There are reports on the increasing prevalence of idiopathic peptic ulcer ${ }^{(4,5,9,15)}$. In period A, around $10 \%$ of our patients presented idiopathic peptic ulcer, while in period B this diagnosis accounted for more than $20 \%$. This finding suggests that other unknown factors play a role in the pathogenesis of peptic ulcer disease ${ }^{(17)}$. The prevalence of peptic ulcer has decreased as well as $H$. pylori infection, reflecting the improvement of living standards and the widespread treatment for $H$. pylori infection. Our results indicate that the emerging increase of idiopathic ulcer seen in elsewhere, may also be occurring in Brazil. We also need to take in account that the accurate diagnosis of IPUD relies in the exclusion of $H$. pylori infection and the use of NSAIDS ${ }^{(5)}$. Regarding $H$. pylori diagnosis, the possible bias is minimized by histological diagnosis of $H$. pylori using the five biopsies sites recommended by the Sydney system. The information on NSAID intake searched in the patients is not accurate and spurious use of NSAIDS could be possible. On the other hand, this potential bias may lead to underestimate the use of NSAIDS by those patients.

Other important issue that may affect our results is the use of proton pump inhibitors (PPI). The widespread use of PPI could reduce the number of ulcers and induce false negative results of $H$. pylori tests ${ }^{(1)}$. The ulcer reduction due the use of PPI could interfering in our results, but the effects of PPI in the tests result is minimized by the routine in our hospital to recommend patients avoid PPI 2 weeks before an elective endoscopy.

Our study also has the limitations of its design. It may be biased because of the retrospective data collection, as we state before. To minimize this bias we took care in just include patients with complete record of the study outcomes. Furthermore, the study was restricted to a single reference center from the central region of the most Southern State of Brazil, therefore our results cannot be generalized. Cross sectional studies are not appropriate for the assessment of temporal trends, so we need to be careful regarding these changes along the time. In spite of these limitations, our study brings new information on the behavior of peptic ulcer disease and its major risk factors along an interval of ten years. This trend can be explored with more appropriated design.

\section{CONCLUSION}

In two periods with 10 years of interval, we identified a decrease in a prevalence of PUD and $H$. pylori infection. Gastric ulcer became more prevalent and duodenal ulcer had a reduced frequency. Simultaneously, we observed the increase of peptic ulcer associated to NSAID and the rise of idiopathic peptic ulcer.

\section{Author contribution}

Fagundes RB and De Carli DM designed the research protocol. De Carli DM conducted the process for IRB permission and coordinated the data collection. Pires RC, Rohde SL and Kavalco CM collected the data. Fagundes RB performed the data analysis and wrote the manuscript. All authors read and approved the manuscript for submission. 
Carli DM, Pires RC, Rohde SL, Kavalco CM, Fagundes RB. Diferentes frequências da úlcera péptica relacionadas com H. pylori ou AINES. Arq Gastroenterol. 2015,52(1):46-9.

RESUMO - Contexto - A etiologia da úcera péptica vem apresentando mudanças devido à redução da infecção pelo H. pylori. Objetivo - Estimar a prevalência da úlcera péptica em dois períodos com intervalo de 10 anos e comparar a associação com a infecção pelo $H$. pylori com o uso de anti-inflamatórios não esteroides. Método - Revisão de prontuários em dois períodos: A (1997-2000) e B (2007-2010), com busca por úlcera péptica, H. pylori e uso de anti-inflamatórios não esteroides (AINE). Resultados - Úcera péptica apresentou frequência de 30,35\% em A e 20,19\% em B. Infecção por $H$. pylori ocorreu em 73,3\% em A e em 46,4\% em B. Uso de anti-inflamatórios não esteroides ocorreu em 3,5\% em A e em 13,3\% em B. Nenhuma dessas condições esteve associada em 10,4\% e 20,5\% das úlceras em A e B, respectivamente. Comparando os dois períodos, houve redução da úlcera péptica associada à $H$. pylori $(P=0,000)$, aumento das úlceras associadas ao uso de anti-inflamatórios não esteroides $(P=0,000)$ e aumento de úlceras idiopáticas $(P=0,002)$. A associação concomitante de $H$. pylori e anti-inflamatórios não esteroides foi também mais alta em $\mathrm{B}(P=0,002)$. Úlceras gástricas aumentaram e úlceras duodenais diminuíram em B. Conclusões - No intervalo de 10 anos, a prevalência de úlcera péptica diminuiu assim como as úlceras relacionadas com H. pylori e houve um aumento das úlceras associadas ao uso de anti-inflamatórios não esteroides. Houve inversão na frequência das lesões gástricas e duodenais e aumento da prevalência da úlcera idiopática.

DESCRITORES - Úlcera péptica. Helicobacter pylori. Anti-inflamatórios não esteroides. Úlcera gástrica. Úlcera duodenal.

\section{REFERENCES}

1. Adamsson I, Nord CE, Sjostedt S, Wikstrom B, Seensalu R. The value of different detection methods of Helicobacter pylori during treatment. J Clin Gastroenterol. 1998;27:138-42.

2. Arents NL, Thijs JC, Van Zwet AA, Kleibeuker JH. Does the declining prevalence of Helicobacter pylori unmask patients with idiopathic peptic ulcer disease? Trends over an 8 year period. Eur J Gastroenterol Hepatol. 2004;16:779-83.

3. Arroyo MT, Forne M, De Argila CM, Feu F, Arenas J, et al. The prevalence of peptic ulcer not related to Helicobacter pylori or non-steroidal anti-inflammatory drug use is negligible in Southern Europe. Helicobacter. 2004;9:249-54.

4. Charpignon C, Lesgourgues B, Pariente A, Nahon S, Pelaquier A, Gatineau-Sailliant G, et al. Peptic ulcer disease: one in five is related to neither Helicobacter pylori nor aspirin/NSAID intake. Aliment Pharmacol Ther. 2013;38:946-54.

5. Chow DK, Sung JJ. Non-NSAID Non-H. Pylori ulcer disease. Best Pract Res Clin Gastroenterol. 2009;23:3-9.

6. Dixon MF, Genta RM, Yardley JH, Correa P. Classification and grading of gastritis. The updated sydney system. International workshop on the histopathology of gastritis, Houston 1994. Am J Surg Pathol. 1996;20:1161-81.

7. Garcia Rodriguez LA, Hernandez-Diaz S, De Abajo FJ. Association between aspirin and upper gastrointestinal complications: systematic review of epidemiologic studies. Br J Clin Pharmacol. 2001;52:563-71.

8. Groenen MJ, Kuipers EJ, Hansen BE, Ouwendijk RJ. Incidence of duodenal ulcers and gastric ulcers in a Western population: back to where it started. Can J Gastroenterol. 2009;23:604-8.

9. Jang HJ, Choi MH, Shin WG, Kim KH, Chung YW, Kim KO, et al. Has peptic ulcer disease changed during the past ten years in Korea? A prospective multi-center study. Dig Dis Sci. 2008;53:1527-31.

10. Kuipers EJ, Thijs JC, Festen HP. The Prevalence of Helicobacter pylori in peptic ulcer disease. Aliment Pharmacol Ther. 1995;9(Suppl 2):59-69.

11. Leong RW. Differences in peptic ulcer between the East and the West. Gastroenterol Clin North Am. 2009;38:363-79.

12. Marques SB, Mattar R, Artifon EL, Sakai P, Carrilho FJ. High prevalence of duodenal ulcer in a tertiary care hospital in the city of São Paulo, SP, Brazil. Arq Gastroenterol. 2011;48:171-4.

13. Marshall BJ, Warren JR. Unidentified curved bacilli in the stomach of patients with gastritis and peptic ulceration. Lancet. 1984;1:1311-5.
14. Mcjunkin B, Sissoko M, Levien J, Upchurch J, Ahmed A. Dramatic decline in prevalence of Helicobacter pylori and peptic ulcer disease in an endoscopy-referral population. Am J Med. 2011;124:260-4.

15. Musumba C, Jorgensen A, Sutton L, Van ED, Moorcroft J, Hopkins M, et al. The relative contribution of nsaids and Helicobacter pylori to the aetiology of endoscopically-diagnosed peptic ulcer disease: observations from a tertiary referral hospital in the UK between 2005 and 2010. Aliment Pharmacol Ther 2012;36:48-56.

16. Nakajima S, Nishiyama Y, Yamaoka M, Yasuoka T, Cho E. Changes in the prevalence of Helicobacter pylori infection and gastrointestinal diseases in the past 17 years. J Gastroenterol Hepatol. 2010;25(Suppl 1):S99-S110.

17. Niv Y, Boltin D. Secreted and membrane-bound mucins and idiopathic peptic ulcer disease. Digestion. 2012;86:258-63.

18. Papatheodoridis GV, Sougioultzis S, Archimandritis AJ. Effects of Helicobacter pylori and nonsteroidal anti-inflammatory drugs on peptic ulcer disease: a systematic review. Clin Gastroenterol Hepatol. 2006;4:130-42.

19. Rodrigues MN, Queiroz DM, Rodrigues RT, Rocha AM, Luz CR, Braga LL. Prevalence of Helicobacter pylori infection in Fortaleza, Northeastern Brazil. Rev Saude Publica. 2005;39:847-9.

20. Santos IS, Boccio J, Santos AS, Valle NC, Halal CS, Bachilli MC, Lopes RD. Prevalence of helicobacter pylori infection and associated factors among adults in Southern Brazil: a population-based cross-sectional study. BMC Public Health. 2005;5:118.

21. Saul C, Teixeira CR, Pereira-Lima JC, Torresini RJ. [Prevalence reduction of duodenal ulcer: a Brazilian study. (retrospective analysis in the last decade: 19962005)]. Arq Gastroenterol. 2007;44:320-4.

22. Sbrozzi-Vanni A, Zullo A, Di GE, Hassan C, Corleto VD, Lahner E, Annibale B Low prevalence of idiopathic peptic ulcer disease: an Italian endoscopic survey. Dig Liver Dis. 2010;42:773-6.

23. Veras RP. Brazil is getting older: demographic changes and epidemiological challenges. Rev Saude Publica. 1991;25:476-88.

24. Yakoob J, Jafri W, Jafri N, Islam M, Abid S, Hamid S, et al. Prevalence of non-Helicobacter pylori duodenal ulcer in Karachi, Pakistan. World J Gastroenterol. 2005; 11:3562-5.

25. Zaterka S, Eisig JN, Chinzon D, Rothstein W. Factors related to Helicobacter pylori prevalence in an adult population in Brazil. Helicobacter. 2007;12:82-8.

Received 24/5/2014 Accepted 22/7/2014 